\title{
Reactive Ion Etching in the Gaseous Electronics Conference RF Reference Cell
}

M. L. Brake, J. T. P. Pender, ${ }^{1}$ M. J. Buie, ${ }^{2}$ A. Ricci, and J. Soniker

Department of Nuclear Engineering, University of Michigan,

Ann Arbor, MI 48109

and

\section{P. D. Pochan ${ }^{1}$ and P. A. Miller}

Sandia National Laboratories, Albuquerque, NM 87106
This paper describes the results of using the GEC reference cell as a reactive ion etcher. Silicon wafers with layers of polysilicon and silicon dioxide on crystaline silicon patterned with photoresist have been investigated with fluorine and chlorine chemistries. Scanning electron microscopy (SEM), profilometry, and refraction techniques were used to determine the etch parameters such as etch rate, uniformity and selectivity. The discharges are in general monitored by measuring the optical emission spectroscopy and the bias voltages. For fluorine chemistries, etch rates ranged from $5 \mathrm{~nm} / \mathrm{min}$ to $177 \mathrm{~nm} / \mathrm{min}$, and for chlorine chemistries, etch rates ranged from $25 \mathrm{~nm} / \mathrm{min}$ to $90 \mathrm{~nm} / \mathrm{min}$.

\begin{abstract}
Depending upon the discharge and chemistry conditions, similar etch rates and etch patterns of different GEC cells were obtained. Etch rates and relative fluorine concentrations obtained from a commercial etcher were compared to the GEC reference cell and were found to be similar although the GEC cell generally gave lower etch rates than the commercial etcher.
\end{abstract}

Key words: discharge; etch depth; etch rate; etching; gaseous electronics; radio frequency; reactive ion etching.

Accepted: March 27, 1995

\section{Introduction}

The increased use of radio-frequency (rf) glow discharges in microelectronics fabrication has resulted in the need for greater comprehension and control of the discharges. One of the most important factors affecting plasma behavior is the geometry of the discharge chamber, as minor alterations in design result in large variations in plasma parameters and hence in etching results. In industry, apparently identical commercial etchers can behave differently. Because of the number of different systems used, it is difficult to compare data from machines of differing properties. A standardized discharge chamber was designed so that models and measurements at different locations could be directly compared. This chamber is known as the GEC Reference cell. The cell was designed as a standardized chamber with the

\footnotetext{
${ }^{1}$ Current address: Dept. of Chemical and Nuclear Engineering, University of New Mexico, Albuquerque, NM 87131.

${ }^{2}$ Current address: Applied Materials, 3320 Scott Blvd., Santa Clara, CA 95054.
}

ultimate goal of understanding the processes that take place in discharges used in microelectronics fabrication. This paper describes the etching that has been performed in several GEC cells, and also gives the results of one study which compared the etching performance of the GEC cell with a commercial etcher. A detailed description of the GEC cell can be found in Ref. [1].

In spite of the fact that the GEC cell was designed as a test bed for diagnosing $13.56 \mathrm{MHz}$ parallel plate discharges similar to those used in industry, only a few groups have examined etching in the GEC cell [2-10]. All of the groups have looked at the etching of silicon, polysilicon and silicon dioxide, but none have tried to make an actual device. All of the groups have used the GEC cell in the reactive ion etcher mode (RIE), where the bottom electrode is powered and the upper electrode and walls of the chamber are grounded. To date there has been only one study comparing the etching ability of the GEC cell to a commercial reactor [2, 3] although a 
commercial cell and a GEC cell were compared in studies of particle formation [10]. One major disadvantage of the current GEC cell is the $10 \mathrm{~cm}$ electrodes were designed when most groups were using $7.6 \mathrm{~cm}$ wafers. Many labs have since upgraded to $10 \mathrm{~cm}$ and larger wafers.

Different chemistries have been examined by different groups. Pender and Buie [2-5] have studied plasma and wafer uniformity as well as etch performance by concentrating on $\mathrm{CF}_{4}$ and $\mathrm{CF}_{4} / \mathrm{O}_{2}$ to etch photoresist patterned wafers with and without silicon dioxide films covered with polysilicon layers. Lane [6] has examined end-point detection of polysilicon, oxide, and nitride films using $\mathrm{SF}_{6} / \mathrm{O}_{2}, \mathrm{CF}_{4} / \mathrm{H}_{2}$, and $\mathrm{CF}_{4} / \mathrm{O}_{2}$, respectively. Pochan and Miller [7] have investigated GEC etch performance by etching silicon covered with polysilicon, patterned with photoresist using $\mathrm{Cl}_{2}$ and $\mathrm{Cl}_{2} / \mathrm{HBr}$ chemistries. Oh et al. [ 8] have etched silicon and silicon dioxide in $\mathrm{CF}_{4} / \mathrm{CHF}_{3}$ mixtures while developing a diode laser absorption technique. Splichal and Anderson [9] have studied resist patterned wafers over a thermal oxide layer while testing optical emission diagnostics for process systems in $\mathrm{CF}_{4} / \mathrm{CHF}_{3}$. Anderson et al. [10] have etched oxide wafers in both a Drytek Quad Model $^{3} 480$ RIE and in the GEC cell in $\mathrm{C}_{2} \mathrm{~F}_{6}-\mathrm{CHF}_{3}$, but studied particle contamination rather than etch performance [10]. Look for an accompanying article in this journal for details of this experiment. A summary of the above mentioned studies is given below.

\section{Experimental Technique}

As mentioned in the introduction, all of the experiments described in this paper used the GEC cell in the reactive ion etcher mode; the top electrode and side walls of the chamber were grounded and the bottom electrode was powered with $13.56 \mathrm{MHz}$ rf power. Usually a matching network was used and in some cases a shunt circuit was also used. The electrode spacing was typically $2.54 \mathrm{~cm}$. At the Universities of Michigan [2-5] and New Mexico [8-9] the wafers were placed on the bottom electrode through a hinged optical port that opened up to the atmosphere to allow access to the cell. Sandia National Laboratories [7] and the Rochester Institute of Technology [6] used a load locked system to place the wafer on the bottom electrode under vacuum conditions. The wafers etched in these studies had a typical pattern shown in Fig. 1. A typical wafer consisted of either p- or n-type silicon covered by a thin thermal oxide layer, followed by a polysilicon layer and topped off with a layer of patterned photoresist. In some of the uniformity studies by Buie $[4,5]$ photoresist patterned silicon wafers without the poly and oxide layers were used since etch depth uniformity was the outcome of interest. Note that the photoresist is used to mask off part of the wafer for etch depth determination. The masks in general are simply test patterns rather than patterns used in making electronic devices.

Etch depth was determined by measuring the etch thickness before and after the etch (etch times are

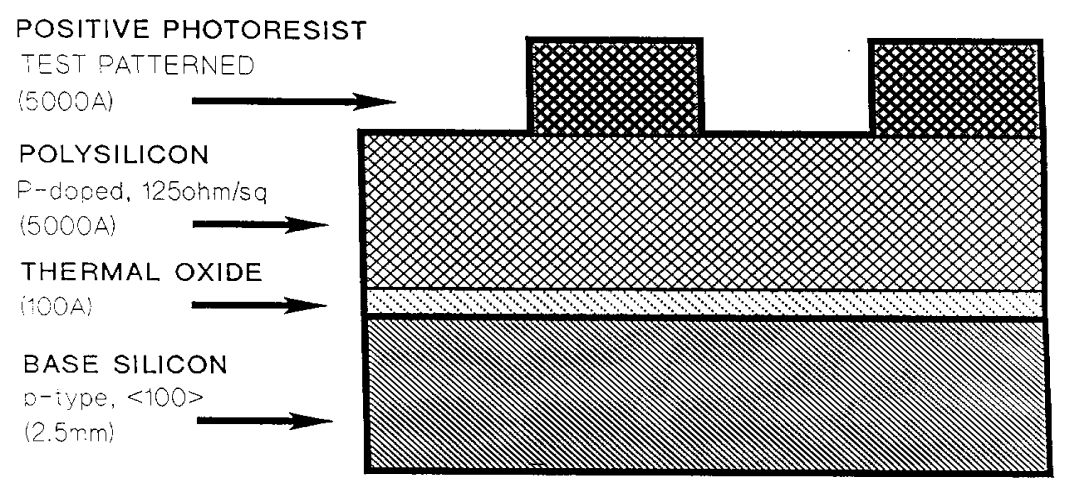

Fig. 1. Schematic of a typical wafer.

\footnotetext{
${ }^{3}$ Certain commercial equipment, instruments, or materials are identified in this paper to foster understanding. Such identification does not imply recommendation or endorsement by the National Institute of Standards and Technology, nor does it imply that the materials or equipment identified are necessarily the best available for the purpose.
} 
typically $30 \mathrm{~min}$ for fluorine based chemistries and a few minutes for the chlorine based chemistries) using a reflectometer [2,3,7]. Scanning Electron Microscopy (SEM) $[2,3,7]$ and profilometry $[4,5]$ were used to examine the etch depth (typically of trenches) after the etches to examine both the microscopic and macroscopic features. Since etching plasmas use very reactive gases, there are not many suitable in situ diagnostics. The least invasive and the most common in situ, nonperturbing diagnostic used in the etch experiments was optical emission spectroscopy (OES). OES was used to identify the constituents of the plasma [2,4-6,9] and to determine the endpoint of the etch using actinometry $[2,3,6]$, the ratio of a fluorine emission line to an argon emission line (i.e., determined when the etch had removed the polysilicon layer and had reached the oxide layer), and spatially resolved optical emission of one wavelength to examine the uniformity of the plasma $[4,5]$. Diode laser absorption measurements were also used to determine various chemical constituents of the plasma [8]. In most cases the bias voltage was also measured during the etch. Residual gas analyzers have also been used to examine the gas species during etching [6]. A summary of the results is given in Table 1.

\section{Summary of Etching Experiments}

Buie et al. $[4,5]$ have investigated the correlation between the spatially resolved optical emission spectroscopy (SR-OES) and the uniformity of the etch in $\mathrm{CF}_{4}$ and $\mathrm{CF}_{4} / \mathrm{O}_{2}$ discharges. SR-OES was taken during the etch of photoresist patterned silicon wafers (i.e., without a layer of polysilicon or silicon oxide). The first major result of this study was to show that the plasma etched nonuniformly, which matched previous optical emission studies of Pender et al. [13] and Djurovic et al. [14]. That is, the discharge etched the edges much more quickly than the middle. See Fig. 2 for typical results. Note that lower pressure discharges result in more uniform macroscopic etching. The second result of this study $[4,5]$ was to show that there is a correlation between the emissivity (calculated from Abel inversion of the collected parallel rays of light from the discharge) and the etch depth as a function of power and pressure. A physical model for this correlation, illustrated in Figs. 3 and 4 , has not been developed at this time. Note that $4 \%$ oxygen had to be added to reduce polymerization.

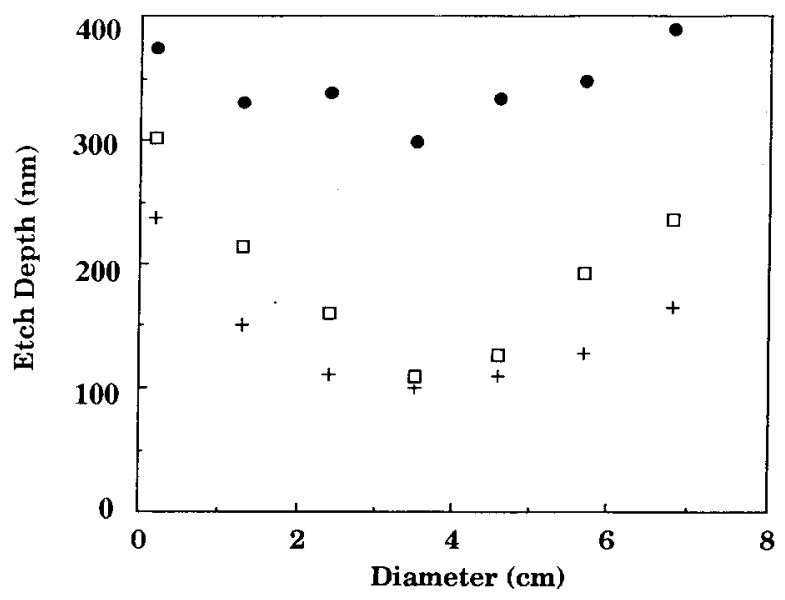

Fig. 2. Etch depth as a function of diameter across the wafer for a $15 \mathrm{~W} \mathrm{CF}_{4} / \mathrm{Ar}$ discharge. Note that etch uniformity improves as the pressure is decreased: $(\bullet) 10 \mathrm{~Pa}(75 \mathrm{mT}),(\square) 20 \mathrm{~Pa}(150 \mathrm{mT})$, and (+) $33 \mathrm{~Pa}$ (250 mT), (see Ref. [4]).

Table 1. A comparison of GEC reference cell etching results

\begin{tabular}{|c|c|c|c|c|c|}
\hline $\begin{array}{l}\text { Etch rate } \\
(\mathrm{nm} / \mathrm{min})\end{array}$ & $\begin{array}{l}\text { Pressure } \\
\quad(\mathrm{Pa})\end{array}$ & $\begin{array}{l}\text { Applied voltage } \\
\text { (V) }\end{array}$ & Chemistry & Material & Ref. \\
\hline 10 to 15 & 6.7 to 33.3 & 190 to $300 \mathrm{~V}$ & $\mathrm{Fl}$ & $\mathrm{Si}$ & {$[4,5]$} \\
\hline 5 to 20 & 6.7 to 33.3 & 80 to $300 \mathrm{~V}$ & $\mathrm{Fl}$ & poly & {$[2,3]$} \\
\hline 50 to 90 & 13.3 & $200 \mathrm{~V}$ & $\mathrm{Cl}$ & poly & [7] \\
\hline 25 to 50 & 13.3 & $200 \mathrm{~V}$ & $\mathrm{Cl}, \mathrm{Br}$ & poly & [7] \\
\hline 9 to 177 & 40 to 93 & 500 to $900 \mathrm{~V}$ & $\mathrm{Fl}$ & oxide & {$[8]$} \\
\hline 1.3 to 115 & 4 to 93 & 500 to $900 \mathrm{~V}$ & $\mathrm{Fl}$ & poly & [8] \\
\hline 8.5 to 60 & 40 to 80 & 500 to $900 \mathrm{~V}$ & $\mathrm{Fl}$ & oxide & [9] \\
\hline
\end{tabular}




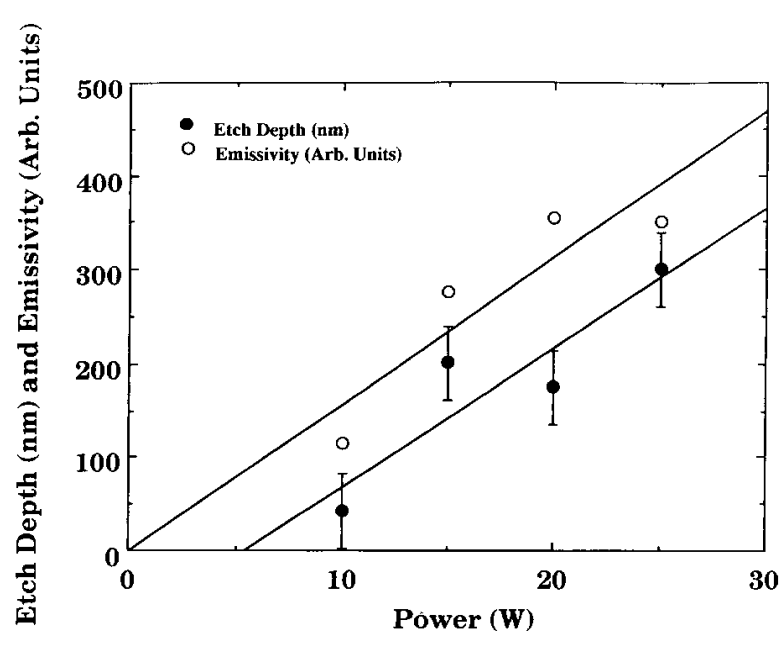

Fig. 3. Etch Depth at the center of the wafer $(\bullet)$ and Emissivity $(O)$ and as a function of power for a pressure of $26.6 \mathrm{~Pa}$ (200 mTorr) in a $\mathrm{CF}_{4} / \mathrm{Ar}$ discharge. Note that both scale linearly (within error) with power.

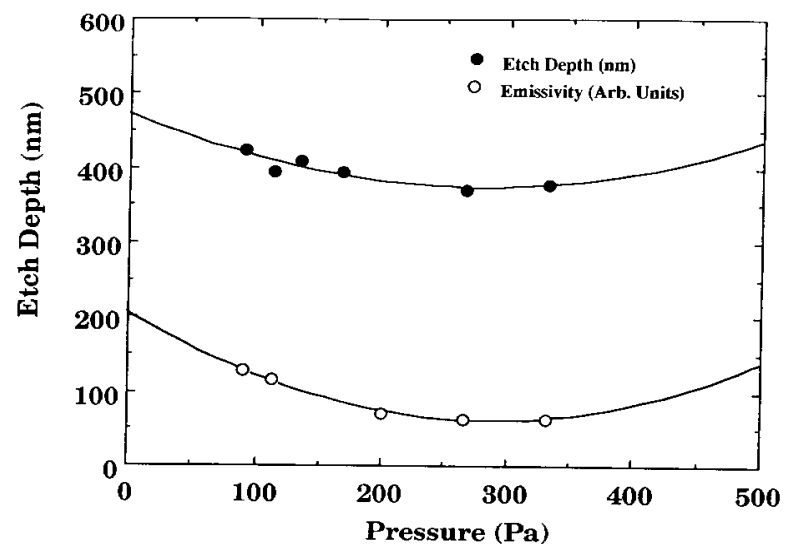

Fig. 4. Etch Depth $(\bullet)$ and emissivity $(O)$ as a function of pressure while etching with $\mathrm{CF}_{4} / \mathrm{Ar} / \mathrm{O}_{2}$ discharges at $20 \mathrm{~W}$ with $4 \%$ oxygen added to the plasma to prevent polymerization. Note that both emissivity and etch depth scale quadratically with pressure, (see Ref. [4]).

In general etch rates of $10 \mathrm{~nm} / \mathrm{min}$ to $15 \mathrm{~nm} / \mathrm{min}$ were measured for $15 \mathrm{~W}$ to $20 \mathrm{~W}$ and a pressure range of 6.7 $\mathrm{Pa}$ to $33.3 \mathrm{~Pa}$ (50 mTorr to $250 \mathrm{mTorr}$ ). Fluorine loading effects were also investigated in this study. Three sets of experiments were conducted. The etch depths resulting from a $7.6 \mathrm{~cm}$ ( 3 in) wafer sitting on the bare aluminum electrode, a $7.6 \mathrm{~cm}$ wafer sitting on a 10 $\mathrm{cm}$ (4 in) wafer on the electrode, and a $7.6 \mathrm{~cm}$ wafer sitting on a quartz plate sitting on the aluminum electrode were measured. The results of this study showed all three conditions gave similar nonuniform etch profiles and etch depths within experimental error. Thus, fluorine loading is not the cause of nonuniform etches.
In a second set of experiments by Pender [2,3], actinometry was used to study etch rates in the cell itself and used to compare with etch studies in a commercial cell. For results of these studies see Secs. 4 and 5. These experiments were conducted in $\mathrm{CF}_{4}$ at flows of 14.9 $\mu \mathrm{mol} / \mathrm{s}(20 \mathrm{sccm})$ with power densities ranging from 25 $\mathrm{mW} / \mathrm{cm}^{3}$ to $60 \mathrm{~mW} / \mathrm{cm}^{3}$. The etch rates ranged from 5 $\mathrm{nm} / \mathrm{min}$ to $20 \mathrm{~nm} / \mathrm{min}$ for $15 \mathrm{~min}$ etches.

Pochan and Miller etched in $\mathrm{Cl}_{2}$ and $\mathrm{Cl}_{2} / \mathrm{HBr}$ plasmas in a Sandia GEC cell [7]. Their wafers were $10 \mathrm{~cm}$ (4 in) diameter of p-type silicon covered with $12 \mathrm{~nm}$ of oxide, $450 \mathrm{~nm}$ of polysilicon and $500 \mathrm{~nm}$ patterned photoresist. They observed etch rates of $50 \mathrm{~nm} / \mathrm{min}$ to $90 \mathrm{~nm} / \mathrm{min}$ with flows of $14.9 \mu \mathrm{mol} / \mathrm{s}(20 \mathrm{sccm})$ of $\mathrm{Cl}_{2}$ and 13.3. Pa (100 mTorr) and peak to peak voltage $\left(\mathrm{V}_{\mathrm{p}-\mathrm{p}}\right)$ of $200 \mathrm{~V}$, $\mathrm{RF}(10 \mathrm{~W})$ power. The $\mathrm{Cl}_{2} / \mathrm{HBr}$ rates span $25 \mathrm{~nm} / \mathrm{min}$ to $50 \mathrm{~nm} / \mathrm{min}$ for flows of $11.2 \mu \mathrm{mol} / \mathrm{s}(15 \mathrm{sccm})$ of $\mathrm{Cl}_{2}$, with flows of $3.7 \mu \mathrm{mol} / \mathrm{s}(5 \mathrm{sccm})$ of $\mathrm{HBr}$, at $13.3 \mathrm{~Pa}$ (100 mTorr) and of $\mathrm{V}_{\mathrm{p}-\mathrm{p}}=200 \mathrm{~V}$. Scanning electron microscope profiles show that the addition of $\mathrm{HBr}$ changes the etch profile from isotropic to anisotropic. The etch rate as a function of power and the etch uniformity will be discussed in Sec. 4.

Oh et al. [8] has been developing a diode laser absorption diagnostic to be used for in situ measurements of $\mathrm{CF}_{4}, \mathrm{CF}_{2}$, and $\mathrm{CF}_{2} \mathrm{O}$, as well as for end point detection during the etching of $\mathrm{SiO}_{2}$. Two types of wafers were used in their study, a blanket thermal oxide $(800 \mathrm{~nm}-$ $1000 \mathrm{~nm}$ ) on n-type silicon wafers for the end-point determination and a half-and-half oxide/polysilicon $(800 \mathrm{~nm}-1000 \mathrm{~nm})$ layered p-type wafers for selectivity determination. The wafers used in the selectivity studies were also patterned with a $500 \mathrm{~nm}$ layer of photoresist. The film thickness for the selectivity experiments was measured before and after etching with an interferometer. The blanket wafers were etched to end point. The oxide etch rates ranged from $9.28 \mathrm{~nm} / \mathrm{min}$ to 176.74 $\mathrm{nm} /$ min using pressures ranging from $40 \mathrm{~Pa}$ to $93 \mathrm{~Pa}$ (300 mTorr to 700 mTorr), various mixtures of $\mathrm{CF}_{4} / \mathrm{CHF}_{3}$ flow rates, and peak to peak voltages of $500 \mathrm{~V}$ to $900 \mathrm{~V}$. The $\mathrm{CHF}_{3}$ ranged from $4.8 \%$ to $33.3 \%$. The poly/Si etch rates ranged from $1.3 \mathrm{~nm} / \mathrm{min}$ to 115 $\mathrm{nm} / \mathrm{min}$ over the same pressure and applied voltage range as the oxide studies. Oxide to poly selectivity was found to range from 0.93 to 3.05 . The conclusions of their study were that by monitoring the feed gas dissociation it might be possible to provide an indicator which could be related to process parameters such as etch rate, selectivity, and anisotropy. They did not draw any conclusions regarding the etching ability of the GEC cell since their main objective was to study this new diode laser diagnostic.

Splichal and Anderson [9] have examined the application of spectral signature analysis techniques 
to silicon dioxide etching in $\mathrm{CF}_{4} / \mathrm{CHF}_{3}$. They used the GEC cell to etch $10 \mathrm{~cm}$ wafers with $830 \mathrm{~nm}$ of thermal oxide covered with a $1.7 \mu \mathrm{m}$ positive resist pattern that exposed approximately $60 \%$ of the oxide film. They measured etch rates ranging from $8.5 \mathrm{~nm} / \mathrm{min}$ to 59.8 $\mathrm{nm} / \mathrm{min}$ for applied peak to peak voltages of $500 \mathrm{~V}$ to $800 \mathrm{~V}$, pressures of $40 \mathrm{~Pa}$ to $80 \mathrm{~Pa}(300$ mTorr to 600 mTorr) and $\mathrm{CHF}_{3}$ of $3.2 \%$ to $41.2 \%$. They concluded that the application of chemometrics to OES was a promising technique for plasma monitoring.

At the Rochester Institute of Technology, Lane and Grimsley [12] are investigating deep etching ( $3 \mu \mathrm{m}$ to $5 \mu \mathrm{m})$ of crystalline silicon with the goal of achieving very smooth etched surfaces, both horizontal and sidewall. In this work, the primary etchant is $\mathrm{SF}_{6}$ with small additions of various other gases. They are finding that very small quantities ( $2 \%$ to $5 \%$ ) of oxygen, hydrogen and other gases have a large effect on the smoothness of the etched surfaces.

\section{A Comparison of Data Taken on Dif- ferent Cells Using the Same Technique}

Even though etch chemistries were different, the etch profiles (etch rate or depth versus distance across the wafer) for wafers illustrated in Fig. 1 were very similar for etching experiments performed at the Univ. of Michigan [2-5] and Sandia [7]. They showed large etch depths at the edge of the wafers compared to the center. Michigan generally etched between $15 \mathrm{~min}$ and $30 \mathrm{~min}$ in $\mathrm{CF}_{4}$ sometimes with $\mathrm{O}_{2}$ added, whereas Sandia etched for a few minutes using $\mathrm{Cl}_{2}$ occasionally adding $\mathrm{HBr}$. Both systems showed an increase in nonuniformity at the edges with increasing applied voltage or power, see Figs. 5 and 6 . The etch rate at the edges showed large increases with power, see Figs. 7 and 8. There is however a disagreement in the functional dependence of rate with increasing power at the center of the wafer. The Michigan [5] results show an increase in etch depth at the center (see Fig. 3) as a function of power. The Sandia [7] group showed no increase in etch rate in the center of the wafer as a function of power, see Fig. 9. This may be due to chemistry effects but this result needs to be examined further. Also, Sandia etched through polysilicon to oxide whereas the Michigan group etched directly into the Si wafer.

\section{A Comparison with a Commercial RIE}

A SEMI Group 1000 TP/CC RIE, housed in a clean room, was chosen for comparison with the GEC cell $[2,3]$. Both are parallel plate, $\mathrm{rf}$ systems operating in an
RIE mode. Both introduced gas into the discharge via a showerhead configuration in the upper electrode. See Table 2 for a comparison of the two systems. Note from the table that the major difference between the two systems was the size and spacing of the electrodes. The etch depth was determined by measuring the poly thickness before and after the etch using a reflectometer and the fluorine concentration was monitored in situ with actinometry, (a process where the intensity of a fluorine optically emitted spectral line is compared to an argon emitted line). Since the distance between electrodes on this GEC cell was fixed, the effect of changing the plate spacing on the GEC cell was not examined. (The SEMIGroup RIE has movable electrodes.)

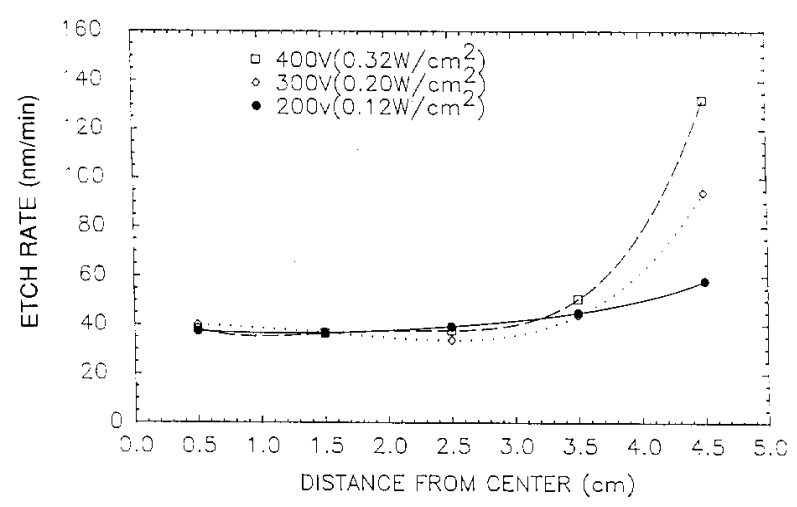

Fig. 5. Etch rate measured from the center of the wafer for three applied voltages in a $\mathrm{Cl}_{2}$ etch at $13.3 \mathrm{~Pa}$ (100 mTorr).

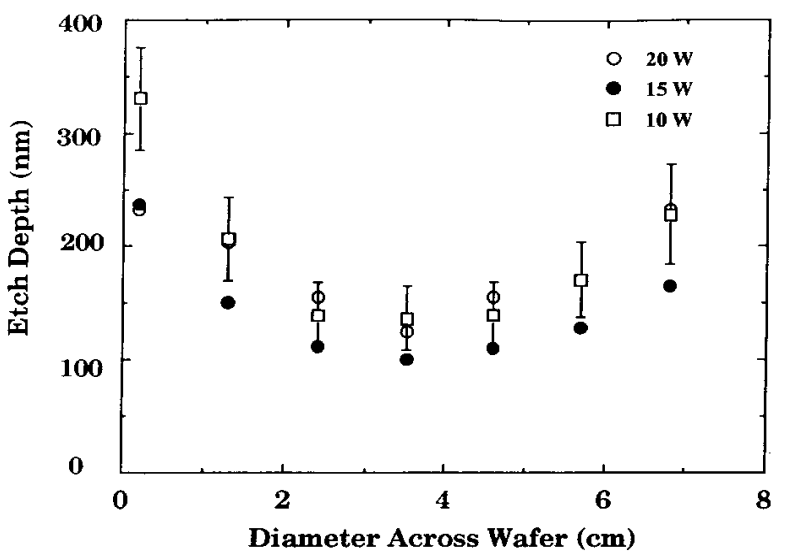

Fig. 6. Etch depth at the center of the wafer as a function of diameter across the wafer for three different powers $(20 \mathrm{~W}(0), 15 \mathrm{~W}(\bullet), 10 \mathrm{~W}$ ( $\square$ )) where the wafers were etched in $\mathrm{CF}_{4} / \mathrm{Ar}$ for 30 minutes at $33 \mathrm{~Pa}$ (250 mTorr). 


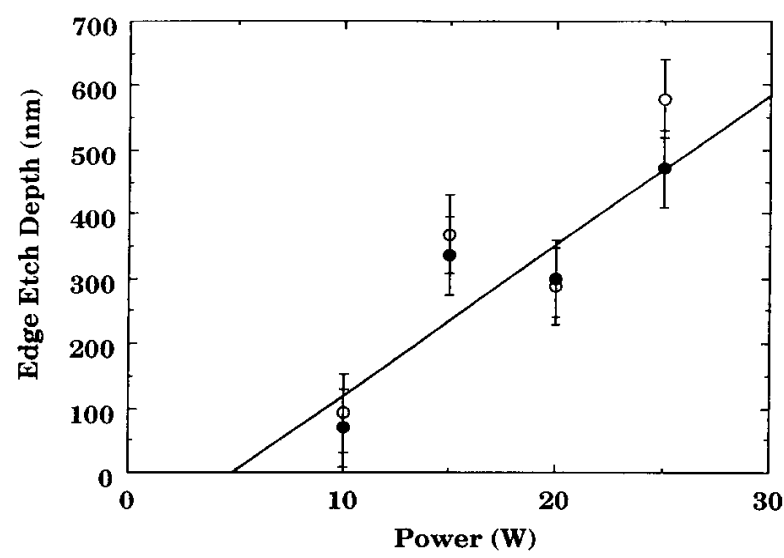

Fig. 7. Etch depth at the two edges of the wafer as a function of power for wafers etched in $\mathrm{CF}_{4}$ for $30 \mathrm{~min}$ at $36.6 \mathrm{~Pa}$ (200 mTorr).

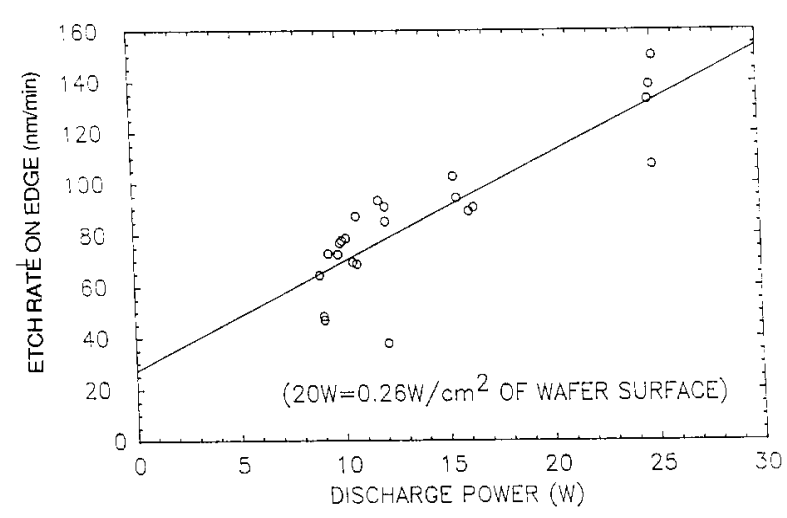

Fig. 8. Etch rates at the edge of the wafer as a function of power for wafers etch in $\mathrm{Cl}_{2}$ at $13.3 \mathrm{~Pa}$ (100 mTorr).

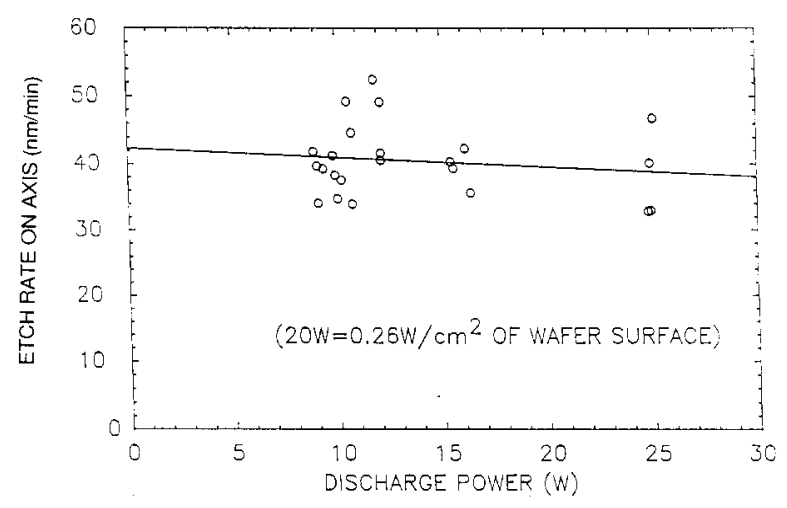

Fig. 9. Etch rate at the center of the wafer as a function of power for wafers etched in $\mathrm{Cl}_{2}$ at $13.3 \mathrm{~Pa}$ (100 mTorr).
Table 2. A comparison of the construction of the SEMI Group RIE and GEC Reference Cell

\begin{tabular}{lcc}
\hline \hline & SEMI Group & UM GEC Ref. Cell \\
\hline Electrode material & Aluminum & Aluminum \\
Powered electrode & Lower & Lower \\
Insulator & Ceramic & Teflon \\
Upper electrode dia. & $40 \mathrm{~cm}$ & $10 \mathrm{~cm}$ \\
Lower electrode dia. & $30 \mathrm{~cm}$ & $10 \mathrm{~cm}$ \\
Electrode spacing & $2.5 \mathrm{~cm} \mathrm{to} 15 \mathrm{~cm}$ & $2.5 \mathrm{~cm}$ \\
Chamber diameter & $43 \mathrm{~cm}$ & $25 \mathrm{~cm}$ \\
Frequency & $13.56 \mathrm{MHz}$ & $13.56 \mathrm{MHz}$ \\
Power Supply & RFX600 600 W & ENI AGC-5 500 W \\
Matching network & MCS ATN 500B & ENI \\
Pressure & $6.7 \mathrm{~Pa}-133 \mathrm{~Pa}$ & $6.7 \mathrm{~Pa}-133 \mathrm{~Pa}$ \\
& $(50 \mathrm{mTorr}$ to $1 \mathrm{Torr})$ & \\
$\mathrm{CF}_{4}$ flow rate & $0 \mathrm{sccm}-40 \mathrm{sccm}$ & $0 \mathrm{sccm}-40 \mathrm{sccm}$
\end{tabular}

Silicon wafers with $400 \mathrm{~nm}$ polysilicon over $200 \mathrm{~nm}$ thermally grown oxide $\left(\mathrm{SiO}_{2}\right)$, (unpatterned) were etched in $\mathrm{CF}_{4}$ with $4 \%$ argon added for actinometry. The etches were performed for pressures ranging from $10 \mathrm{~Pa}-20 \mathrm{~Pa}$ (75 mTorr to $150 \mathrm{mTorr}$ ) at a flow of 22.4 $\mu \mathrm{mol} / \mathrm{s}(30 \mathrm{sccm})$. See Figs. 10 through 12 for typical results. Note that the etch depths were measured at the center of the wafer for wafers etched in both machines. The final results of this study are that the two cells give similar etch rates and fluorine concentrations if the plate spacing, the flow rate and the power density are similar and, when possible, the bias voltage is the same.

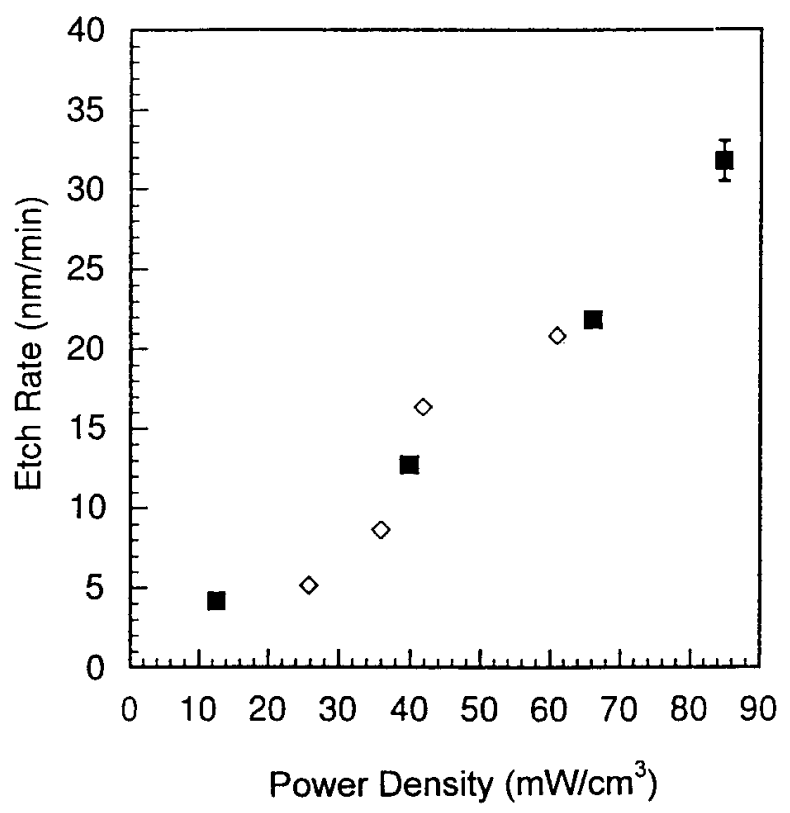

Fig. 10. Etch rate as a function of absorbed power at $10 \mathrm{~Pa}$ (75 mTorr) for the GEC cell $(\diamond)$ and the SEMI Group RIE ( $)$ for wafers etched in $\mathrm{CF}_{4} / \mathrm{Ar}$ for $30 \mathrm{~min}$. 


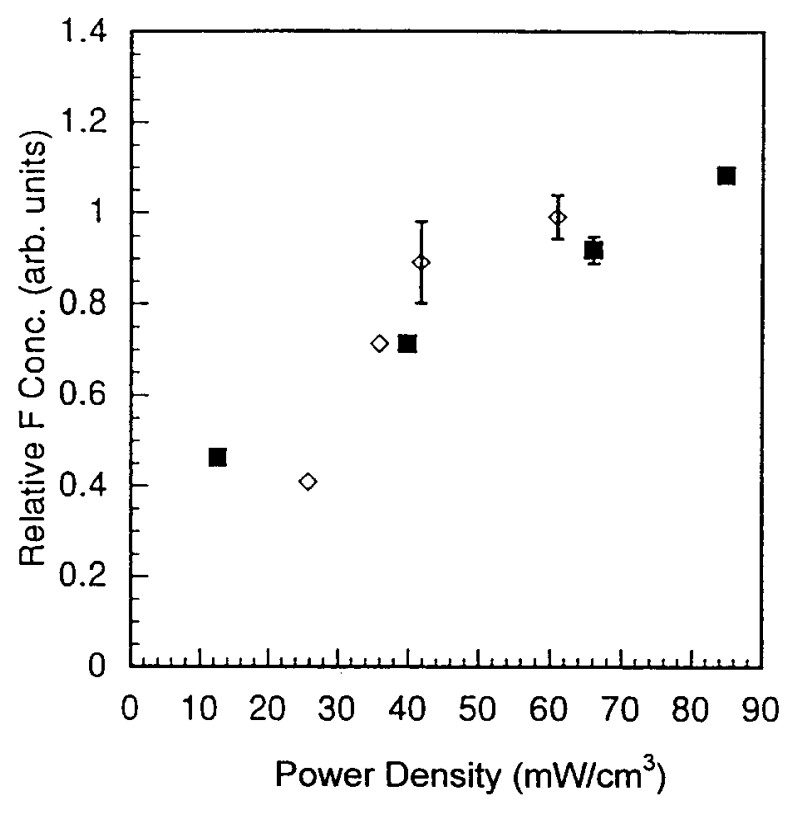

Fig. 11. Fluorine concentration as a function of power density at 10 $\mathrm{Pa}(75$ mTorr) for the GEC cell $(\diamond)$ and the SEMI Group RIE (ם ) for wafers etched in $\mathrm{CF}_{4} / \mathrm{Ar}$ for $30 \mathrm{~min}$.

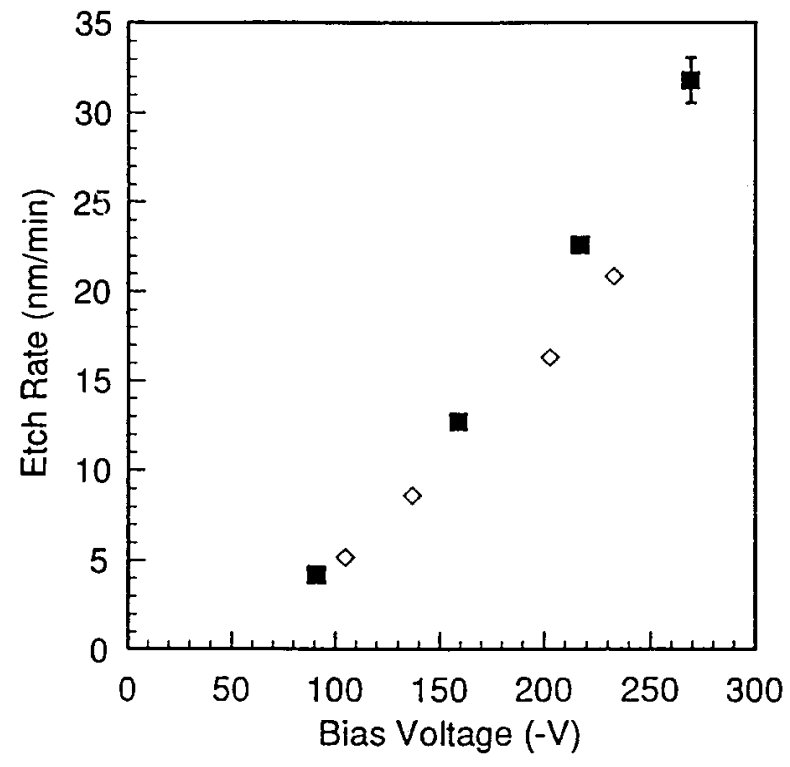

Fig. 12. Etch rate as a function of bias voltage at $10 \mathrm{~Pa}(75 \mathrm{mTorr})$ for the GEC cell $(\diamond)$ and the SEMI group RIE ( $\square$ ) for wafers etched in $\mathrm{CF}_{4} / \mathrm{Ar}$ for $30 \mathrm{~min}$.

In this same study, the power absorbed by the cells was determined with simple circuit models [2]. The circuit model used for the GEC was that developed by Miller and Kamon [11], and for details of the model used for measuring and calculating the power of the commercial cell, see Ref. [2]. As seen in Figs. 13a and $13 \mathrm{~b}$, the power measured from the power supply was actually much larger than the power absorbed by the discharge for both the GEC and SEMI-Group cells.

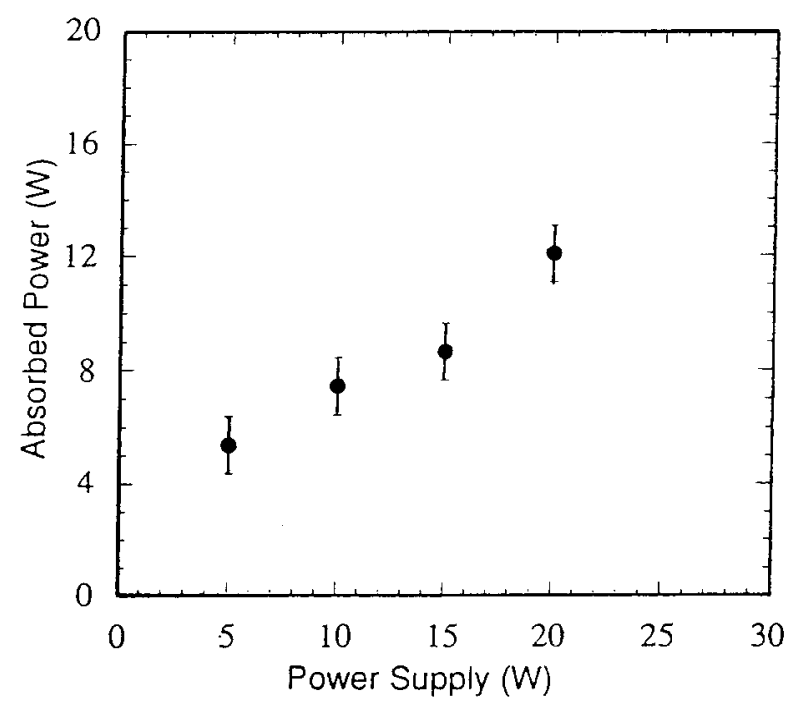

Fig. 13a. Absorbed power as a function of power read from the power supply dial on the ENI power supply used with the GEC Reference Cell.

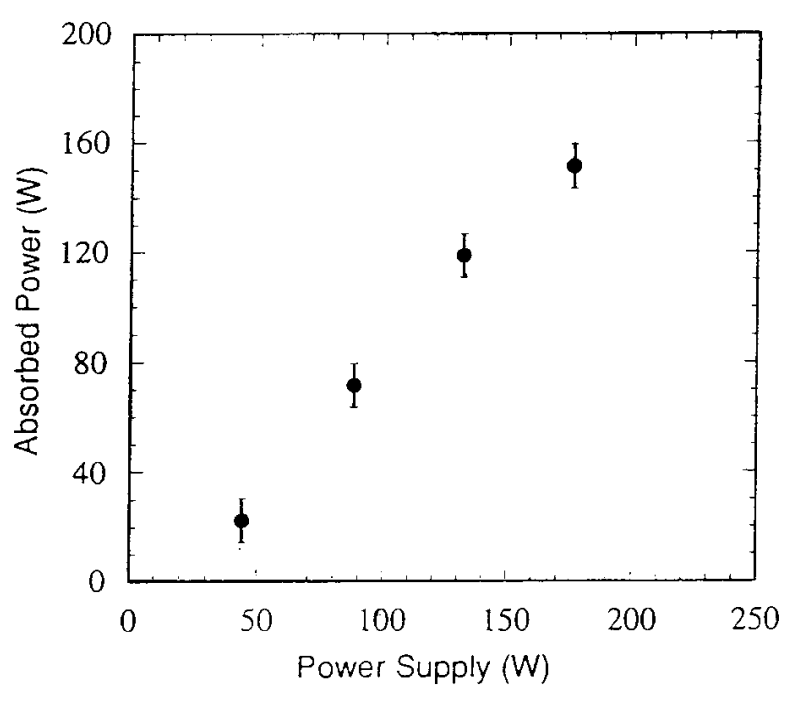

Fig. 13b. Absorbed power as a function of power read from the power supply dial on the SEMI Group RIE. 


\section{Conclusions}

The GEC Reference Cell has been used as an etcher of silicon materials at four locations, University of Michigan, University of New Mexico, Rochester Institute of Technology, and Sandia National Laboratories. In general, similar current and voltage waveforms gave similar etch rates and etch patterns in all four cells depending upon the chemistry. The resulting etch of the wafers however was not uniform. This nonuniformity can be examined with optical emission spectroscopy and other diagnostics (see accompanying papers in this Special Issue of this journal). In one study, the GEC as used as a reactive ion etcher was compared to a commercial parallel plate system, and was found to give lower etch rates but similar etch patterns.

\section{Acknowledgments}

The authors would like to acknowledge support from SRC contract \#94-MC-085 (Michigan), SEMATECH under contract DE-FI04-89AL588772 (Sandia), the U.S. Department of Energy under contract DE-AC0494AL85000, and the sharing of data by Richard Lane and Harold Anderson and their associates.

\section{References}

[1] P. J. Hargis, Jr., K. E. Greenberg, P. A. Miller, J. B. Gerardo, J. R. Torczynski, M. E. Riley, G. A. Hebner, J. R. Roberts, J. K. Olthoff, J. R. Whetstone, R. J. Van Brunt, M. A. Sobolewski, H. M. Anderson, M. P. Splichal, J. L. Mock, P. Bletzinger, A. Garscadden, R. A. Gottscho, G. Selwyn, M. Dalvie, J. E. Heidenreich, J. W. Butterbaugh, M. L. Brake, M. L. Passow, J. Pender, and A. Lujan, M. E. Elta, D. B. Graves, H. H. Sawin, M. J. Kushner, J. T. Verdeyen, R. Horwath, and T. R. Turner, The Gaseous Electronic Conference radio-frequency reference cell: A defined parallel-plate radio-frequency system for experimental and theoretical studies of plasma-processing discharges, Rev. Sci. Instrum. 65 (1), 140 (1994).

[2] J. T. P. Pender, A comparison of etching conditions in the GEC Reference Cell to a commercial reactive ion etcher, Ph.D. Dissertation, University of Michigan (1994).

[3] J. T. P. Pender, M. J. Buie, M. E. Elta, and M. L. Brake, Comparison of $\mathrm{Si}$ etching in the GEC reference cell and a commercial reactive ion etcher, submitted for publication.

[4] M. J. Buie, J. T. Pender, J. Soniker, M. Elta, and M. L. Brake, In situ diagnostic for etch uniformity, J. Vac. Sci. and Tech. A, in press (Aug. 1995).

[5] M. J. Buie, Uniformity studies of RF plasmas, Ph.D. Dissertation, University of Michigan (1994).

[6] R. L. Lane and T. J. Grimsley, Plasma standard cell for laboratory demonstrations and experiments, proceedings of the 10th Biennial University/Governiment/Industry Microelectronics Symposium at Research Triangle Park, May 18-19, 1993, pp. 213-218.
[7] P. D. Pochan and P. A. Miller, Etching results from the GEC RF reference cell, 44th Gaseous Electronics Conference, Albuquerque, NM, Oct. 22-25, 1991.

[8] D. B. Oh, A. C. Stanton, H. Anderson, and M. Splichal, In situ diode laser absorption measurements of plasma species in a GEC reference cell reactor, J. Vac. Sci. Tech. B 13, 954 (1995).

[9] M. Splichal and H. Anderson, Application of chemometrics to optical emission spectroscopy for plasma monitoring, SPIE 1594, 189 (1991)

[10] H. Anderson, S. Radovanov, J. Mock, and P. Resnick, Particulates in $\mathrm{C}_{2} \mathrm{~F}_{6}-\mathrm{CHF}_{6}$ and $\mathrm{CF}_{4}-\mathrm{CHF}_{3}$ etching plasmas, Plasma Sources Sci. Technol. 3, 302-309 (1994).

[11] P. A. Miller and M. Kamon, Sandia Natl. Lab. Report No. SETEC 90-009 (1990).

[12] Richard Lane, private communication.

[13] J. Pender, M. Buie, T. Vincent, J. Holloway, M. Elta, and M. L. Brake, Radial optical emission profiles of radio frequency glow discharges, J. Appl. Phys. 74 (5), 3590 (1993).

[14] S. Djurovic, J. R. Roberts, M. A. Sobelewski, and J. K. Olthoff, Absolute spatially- and temporally-resolved optical emission measurements of rf glow discharges in argon, J. Res. Natl. Inst. Stand. Technol. 98, 158 (1993).

About the authors: Mary Brake is an Associate Professor in Nuclear Engineering at the University of Michigan. Jerry Pender has recently graduated from the University of Michigan and is currently a Research Assistant Professor at the University of New Mexico. Melisa Buie has recently graduated from the University of Michigan and is a senior process engineer for Applied Materials in Santa Clara, CA. Anthony Ricci is a research assistant and graduate student in the Nuclear Engineering Dept. of the University of Michigan. Jill Soniker is currently a junior in Nuclear Engineering at the University of Michigan. Paul Pochan is a Research Assistant and student in the Dept. of Chemical and Nuclear Engineering at the University of New Mexico. Paul Miller is a member of the technical staff in the Laser, Optics, and Remote-Sensing Department at Sandia National Laboratories. 